\title{
Lapurdum
}

LAPURDUM Euskal ikerketen aldizkaria | Revue d'études basques |

Revista de estudios vascos | Basque studies review

$10 \mid 2005$

Numéro $X$

\section{Galdegaia Bere Bakardadean}

\section{Aritz Irurtzun}

\section{OpenEdition}

\section{Journals}

Édition électronique

URL : http://journals.openedition.org/lapurdum/49

DOI : $10.4000 /$ lapurdum.49

ISSN : 1965-0655

\section{Éditeur}

IKER

Édition imprimée

Date de publication : 31 décembre 2005

Pagination : 95-125

ISBN : 2-86781-409-X

ISSN : $1273-3830$

\section{Référence électronique}

Aritz Irurtzun, « Galdegaia Bere Bakardadean », Lapurdum [Linean], $10 \mid$ 2005, Sarean emana----an 01 avril 2008, kontsultatu 20 septembre 2020. URL : http://journals.openedition.org/lapurdum/49 ; DOI : https://doi.org/10.4000/lapurdum.49 


\title{
Galdegaia Bere Bakardadean
}

\author{
Aritz Irurtzun \\ EHU-UPV, IKER-CNRS \& U. Bordeaux 3
}

\section{§1-Sarrera ${ }^{1}$ :}

Lan honetan galdegaiaren izaera semantiko-pragmatikoa aztertuko dut literaturan aipatu izan diren galdegai motak galdegai bakarrera ekartzeko proposatuz. 2. atalean galdegaiaren afera aurkeztuko dut autore desberdinek proposatu dituzten galdegaiaren natura kontrastibo, informatibo, aurresuposizional, ez-aurresuposizional eta abarrak laburbilduz. Autoreon iritzien aurkezpenaren ostean, heien argudiaketen kritika bat aurkeztuko dut eta nire proposamena egin: galdegai bat besterik ez dago, eta interpretazio-diferentziak epifenomenalak dira. Honela, 3. atalean Herburger (2000) lanean oinarrituz, galdegaiarentzat proposatzen dudan forma logikoa aurkeztuko dut ${ }^{2}$. Galdegaien interpretazioen arteko aldea, ez da galdegaian berean egongo, egitura bakoitzaren kuantifikatzailean baizik: testuingururik gabeko esaldiek informazio berria besterik ez dute emango, hala gertakarien gaineko kuantifikatzaile existentzial batez definituak izango dira. Testuingurudun galdegaietan ordea, galdegai aurresuposizioa eta exhaustibitatea izango ditugu, testuinguruan aipatuak diren gertakarien deskripzio definituak direlako.

\section{§2-Galdegaiaren askotariko izaera}

Eztabaida bizia dago hizkuntzalarien artean galdegaiaren naturi dagokionean, eta ez da beti argi gelditzen askotariko azaleratzeak dituen fenomeno bakar batez ari garen, ala fenomeno desberdinen aurrean gauden. Eztabaida hau, bi ardatz nagusiren inguruan garatzen da:

(1a) Galdegaiaren (balizko) izaera aurresuposizionala.

\footnotetext{
${ }^{1}$ Nire eskerrak agertu nahi nizkieke hemen aurkezten ditudan kontuez nirekin hitz egiteko astia hartu duten Urtzi Etxeberria, Ricardo Etxepare, Elena Herburger, Brenda Laca, Javi Ormazabal, Myriam UribeEtxebarria eta bereziki Maia Duguineri bere iruzkin kritikoengatik. Honek, jakina ez du esan nahi hauek hemen aurkezten ditudanekin ados daudenik. Bertako hutsegite guztiak, beraz, nireak dira. EHUren UPVEHU 9 UPV 00114.130-160.09-2004 diru-laguntzari esker burutu da lan hau.

${ }^{2}$ Lan honetan, bi “forma logiko” desberdinduko dira: Forma Logikoa eta forma logikoa. Lehenengoa, errepresentazio-maila sintaktiko bat da, mugimendu sintaktikoen bidez osatua eta hala, murriztapen sintaktikoak ditu (kategoria hutsaren hatsarrea etab.). Bigarrena, aldiz, hizkuntzaren filosofiazko literaturan erabiltzen den "forma logiko" edo "sintaxi logiko" kontzeptuaren parekoa da, hots, deribazionalki, Forma Logikoaren osteko errepresentazio semantiko-interpretatibo bat. Honenbestez, forma logikoa ez da sintaktikoa (ik. Chomsky (1976) edota Hornstein (1995, 2002) eztabaidarako) eta Chomsky-ren azken lanetako "SEM”-etik hurbilago dago aurreko "Forma Logiko" noziotik baino (ik. Chomsky (2004, 2005)).
} 
(1b) Galdegaiaren (balizko) izaera kontrastiboa.

Jarraian, eztabaidaren bi ardatz hauek izan dituzten gauzapenak laburbilduko ditut geroago ikuspegi bateratu baten bila abiatzeko.

\section{1: Aurresuposizioetatik Alternatiba Multzoetara, eta Atzera Itzulia}

Atal honetan, galdegaiak eragindako aurresuposizioen ideiak literaturan egin duen joan-etorriko bidaia azalduko dut galdegai-aurresuposiziorik baden edo ez den defendatzen dutenen argudioak laburbilduz.

\subsection{1: Galdegaiaren Aurresuposizioen Hutsegitea}

Aitzindariak izan baziren ere (eta horien artean de Rijk (1969) nabarmentzekoa da) Chomsky-ren $(1970,1976)$ lana izan zen lehena Gramatika Sortzaile-Bihurtzailean galdegaiaren tokia zehazten saiatzen. Chomsky-ren arabera, galdegaiak esaldiaren partiketa bitar bat eragiten du, (2a) bezalako perpaus batek (2b)-ko galdegaiaurresuposizio partiketa duela:

(2a) $[\text { Mikelek }]_{\mathrm{F}}$ idazten du poesia.

(2b) Mikel da x-a, [non eta x-k poesia idazten duen].

Chomsky (1976, 1977)-n, hau Forma Logikoaren errepresentazio-maila justifikatzeko ebidentzia bezala erabiltzen da, (2b)-ko egiturara eramango gaituen transformazio sintaktikoak gurutzaketa ahularen efektuak eragiten dituelako. Ingelesezko (3), adibidez, galdegaiaren azentu nuklearra 'John'-en egonik, ezin da ulertu 'John' eta 'he' indizekide (hots, erreferentziakide) bailiran.

(3) The woman he $\mathrm{j}_{\mathrm{j} / \mathrm{i}}$ loved betrayed $\left[\mathrm{John}_{\mathrm{i}}\right]_{\mathrm{F}}$. art. emakume bera maite engainatu John

"John engainatu zuen berak maite zuen emakumeak"

Honela, Chomsky-k galdegaia, Forma Logikoan besarkadura hartzeko ezkutuko mugimendu bat egin behar duen operatzaile bat dela ondorioztatzen du (ingelesari dagokionez bederen). Honek, (2b)-ko errepresentazioa modu natural batean emateaz gain, (3)-ko gurutzaketa ahularen agerrera ere iragarriko du, ezkutuan bada ere, operatzaileak indizekide den izenordain bat gurutzatuko duelako (4), NZ-hitzen ageriko mugimenduetan gertatzen den bezala (5):

(4) $* \mathrm{Op}_{\mathrm{i}} \quad$ Izenordain $_{\mathrm{i}} \quad \mathrm{t}_{\mathrm{i}}$

(5) $* \mathrm{Who}_{\mathrm{i}}$ did his mother see $\mathrm{t}_{\mathrm{i}}$ ?

Nor AUX bere ama ikusi

"Nor ikusi zuen bere amak?”

Honela bada, Chomsky-k galdegai-aurresuposizio dikotomia proposatzeko argudio interpretatiboez gain, argudio gramatikalak ere ematen ditu. 
Berriro ere galdegaiaren izaera eta funtzio semantikora bueltatuz, Jackendoff-en (1972)-ko lana oso mugarri garrantzitsua da galdegaiaren interpretazioaren ikerketan. Autore honek Chomsky-ren galdegai-aurresuposizio oposaketa semantikoki jasotzeko, galdegaiak, (6b)-n eman bezala, bere posizioan existentzialki kuantifikatutako aldagai bat ordezkatzen duela proposatzen du:

(6a) Who likes Bill?

nork maite Bill

"Nork maite du Bill?"

(6b) $\exists x, x-k$ Bill maite du.

(6c) $[\text { John }]_{F}$ likes Bill.

John maite Bill

"Johnek maite du Bill”

Hala ere, Jackendoff-ek berak kuantifikazio existentzial honek berehala arazoak dakartzala aitortzen du. Izan ere, multzo hutsak aldagaia ordezkatzen duenean gertakariaren aurresuposatutako existentziaren eta multzo hutsaren arteko kontraesana sortzen da. Ikus (6d), (6a)-ren erantzun egokia izan daitekeena:

(6d) $[\text { Nobody }]_{F}$ likes Bill. inor maite Bill

"Inork ez du Bill maite"

Bistan denez, (6d)-ko perpausak ezin du (6b)-ko aurresuposizioa eragin, (6b)-ren aurka (6d)-k 'Peru maite duen inor ez dagoela' baieztatzen baitu. Honenbestez, Jackendoff-ek lambda kalkuluko abstrakzioa proposatzen du fenomenoari inongo konpromiso existentzialik gabe aurre egiteko. Bere proposamenaren arabera, galdegai den elementua lambda-abstrakzio bidez ateratzen da eta bere kokapenean bere tipo semantiko bera duen aldagai bat uzten da:

(7a) $[\text { Nobody }]_{F}$ likes Bill. inor maite Bill

"Inork ez du Bill maite"

(7b) $\lambda x, x-k$ Bill maite du.

(7b)-ko irudikapena hartuta, multzo hutsaren arazoari modu sinplean egin dakioke aurre; aldagaia galdegaiaren ordez dago eta gainontzeko zatia hondoaren ${ }^{3}$ ordez, non:

(8)

$$
\lambda x \text { Presupps (x) }\left\{\begin{array}{l}
\text { Multzo koherente bat den } \\
\text { Ongi definitua dagoen } \\
\text { Eztabaidagarria den } \\
\text { Aipagaia den }
\end{array}\right\}^{\text {Oraingo solasaldian }}
$$

Nahiz eta Jackendoff-ek galdegai ez den zatiari 'Presupps' etiketa ematen dion, ohar honelako semantika batekin preseski, $\mathrm{x}-\mathrm{k}$ 'eztabaidagai den funtzio bat' adierazten

\footnotetext{
3 'hondo' hitzarekin ingelesezko background adierazi nahi dut.
} 
duela proposatzen duela. Beraz, aurresuposizioen konpromiso existentzialetik at. Honela bada, propietate hori betetzen duen zerbait baden ala ez irekia gelditzen da.

\subsection{2: Esanahi Dimentsio Aniztasuna eta Alternatiba Multzoak}

Jackendoff-en eredua oinarri hartuta, Rooth (1985)-k esanahi dimentsio aniztasun bat proposatzen du galdegaiaz kontu emateko. Ildo honi jarraituz, perpaus baten ekarpen semantikoa ez litzateke proposizio soil batekoa, hainbat dimentsiotako proposizio multzoak baizik. Hau da, Rooth-en arabera, perpaus baten 'ohiko balioa' $\left([[\Phi]]^{\mathrm{O}}\right)-\mathrm{z}$ gain 'galdegai balioa' $\left([[\Phi]]^{\mathrm{F}}\right)$ ere izango dugu. 'Ohiko balioan', ez da galdegaiaren inongo eraginik izango, hau da, perpausak adierazten duen proposizioa izango da (Grice (1975)-en what is said edo Cappelen \& Lepore (2005)-en semantic content-en parekoa). Bestetik, perpausaren 'galdegai balioa' proposizio multzo bat izango da ( $p$-set, Rooth-en hitzetan). Multzo hau, galdegaia testuinguruan eskuragarri dauden eta tipo semantiko bera duten alternatibekin ordezkatuz eraiki daitekeen proposizio-multzoa izango da ${ }^{4}$. Honela, (9)-ko esaldiak, 'Aitor', 'Miren', 'Amaia', 'Iñaki', 'Idoia' eta 'Leire' testuinguruan eskuragarri egonik, honako bi balioak lituzke (non $E$ banakoen multzoa den):

(9) $[\text { Aitorrek }]_{\mathrm{F}}$ maite du Iñaki.

$[[\Phi]]^{\mathrm{O}}:\{$ maite $(\mathrm{a}, \mathrm{i})\}=[$ [Aitorrek Iñaki maite du $\left.]\right]$

$[[\Phi]]^{\mathrm{F}}:\{$ maite $(\mathrm{x}, \mathrm{i}) \mid \mathrm{x} \in E\}=\{[[$ Aitorrek Iñaki maite du]], [[Mirenek Iñaki maite du]], [[Amaiak Iñaki maite du]], [[Idoiak Iñaki maite du]], [[Leirek Iñaki maite du]]\}

Berriro ere, honelako errepresentazioen arabera, ez legoke galdegaiaurresuposiziorik, soilik eztabaidagai den funtzio bat.

\subsection{3: Kritika Berriak: Aurresuposizioaren Berpiztea}

Ikusi bezala, semantikarien artean galdegaiak aurresuposizio existentzialak eragiten dituelako ideia baztertu samarra egon bada ere, aurresuposizioen intuizioa beti mantendu da. Hala, teknikoki ez bada ere, ikerketari askoren lanetan galdegai vs. aurresuposizio dikotomia aipatzen da, intuitiboki 'aurresuposizioa' 'eztabaidagai den funtzioa’ baino argiagoa delako, eta kasurik gehienetan aurresuposizioak badirelako. Bada berriki, galdegai-aurresuposizioen afera berriro piztu da Theoretical Linguisticseko ale bateko Geurts eta van der Sandt-en artikulu eztabaidatuari esker ${ }^{5}$. Geurts eta van der Sandt (2004a)-k, galdegai-aurresuposioak ukatzen dituen tradizioaren aurka azaltzen dira Hondo-Aurresuposizio Araua deritzotena proposatuz:

(10) Galdegaiak $\lambda x . \varphi(\mathrm{x})$ hondo bat eragiten duenean, badago $\lambda x . \varphi(\mathrm{x})$ banakoren batentzat gauzatzen delako aurresuposizioa.

\footnotetext{
${ }^{4}$ Hau da, funtsean, Hamblin (1973)-en galderen semantikaren arabera, delako perpausak erantzun lezakeen galderaren denotazioa.

${ }^{5}$ Ik. Krifka (2004).
} 
Arau hau proposatzeko birkuantifikazioen arazoarekin argudiatzen dute. Birkuantifikazioaren fenomenoa, galdegaigunean ez den espresio indefinitu bat dagoenean agertzen da, non adierazpen indefinitu hau kuantifikatzaile baten murriztapenean eta besarkaduran interpretatzen den (ik. von Fintel (1994), Rooth (1995), Krifka (2001)). Adibidez:

(11) Zakur bat normalean [adimentsua] $]_{\mathrm{F}}$ da.

(11)-ren irakurketa naturalena 'zakur gehienak adimentsuak direlakoa' da. Beraz, aintzat hartuta 'usually' aditzondo-kuantifikatzaileak gertakari edo egoeragaineko besarkadura hartzen duela, eta galdegaia ez denak kuantifikatzailearen murriztapena adierazten duela, indefinituen analisi dinamiko batek (11)-ren interpretazio bezala (12)-n informalki aurkeztutakoa bezalako zerbait proposatuko luke:

(12) Normalean[zakur bat] [[zakur bat] \& [ adimentsua da]]

Hau da, 'zakur bat baden egoera gehienetan bada adimentsua den zakur bat'. Kontua da (12)-n indefinitua bi aldiz aipatua dugula, eta honelako analisi batek, semantika dinamiko batean (11) gezurtatuko luketen egoera batzuk egiazkotzat joko lituzkeela. Demagun unibertso bat non zakurrak beti binaka datozen, eta non bi zakurretako bat bakarrik den adimentsua. Halako unibertso batean (11) gezurrezkoa da baina (12) egiazkoa. Adibideari korapilatua iritziz gero, pentsa (13)-n:

(13) Beso bat normalean [ezkerreko] $]_{\mathrm{F}}$ sorbaldari atxikia dago.

Egiazki, besoen \%50a izaten da ezkerreko sorbaldari atxikia, beste erdia eskuinekoari atxikitzen zaiolako. Hortaz, esaldia gezurrezkoa da. Baina (13)-ren ildoko forma logiko batek esaldia egiazko egingo zukeen, izan ere, 'beso bat sorbalda bati atxikia dagoen egoera gehienetan bada ezkerreko sorbaldari atxikitako beso bat'.

Geurts \& van der Sandt-en iritziz, birkuantifikazioaren arazoa aurresuposiziouztarketaren arazo orokorragoaren adibide bat besterik ez da. Autore hauek lan honetan azalduko ez dudan aurresuposizio-uztarketaren Discourse Representation Theory ereduko azterketa bat eskaintzen dute. Hemen, besterik gabe, euren ebidentzia galdegaiak eragindako aurresuposizio efektuak badirela erakusteko erabiliko da 3 . atalean analisi alternatibo bat emateko.

\subsection{4: Ondorioak: Aurresuposizio Efektuak}

Galdegaiak aurresuposizioak sortzen baditu aurresuposizio hauek gainontzeko aurresuposizioek dituzten propietateak izan beharko dituzte. Eta halaxe da; galdegaiak eragindako aurresuposizioa beste aurresuposizioak bezalakoxea da:

(14a) [Peioren emazteak $]_{\mathrm{F}}$ ebatsi baditu tartak, orduan Peio errugabea da.

(14b) Peio errugabea bada, orduan [Peioren emazteak $]_{F}$ ebatsi baditu tartak.

Kartunnen (1973)-ri jarraiki, baldintzazko konektiboak (konjuntzioak eta disjuntzioak bezalatsu) aurresuposizio-iragazkiak izango dira; hau da, $\mathrm{p} \rightarrow \mathrm{q}$ bezalako 
perpaus konplexu baten aurresuposizioak p-ren eta q-ren aurresuposizioen multzoa izango da, p-k ekartzen (entail) dituenak kenduta. Honela, bi kasuotan, 'Peioren emaztea' deskripzio definituak eragiten duen aurresuposizioa baldintzazko perpausaren iragazkitik pasatzen da eta bi kasuotan dugu 'Peiok badu emaztea' aurresuposizioa baldintzazko egituraren gainean. Modu bertsuan, hondoak eragindako 'norbaitek tartak ebatsi ditu' aurresuposizioa ere, (14a) eta (14b)-ko bi perpaus osoek dute.

Galdegaiak eragindako aurresuposizioek, beraz, beste aurresuposizioek dituzten propietate bertsuak dituzte. Areago, faktore hau, baldintza kontrafaktualetan ere mantentzen da non baldintzak gertatu ez den gertakari bat definitzen duen. (ik. Dretske (1972), von Fintel (1994), Rooth (1999) eztabaidarako). Adibidez:

(15) Ez bazenu lan handirik egin ez zenukeen azterketa gainditu izango.

Honelako egitura batean, bada aurresuposizio existentziala ('lan handia egin duzu eta azterketa gainditu duzu’). Orain, demagun ondoko testuingurua dugula (ik. Rooth (1999)):

(16) Marijosek bi alaba ditu: Maialen eta Ainara. Ainarak amarekin egiten du lan taberna batean eta lanean oso beharrezkoa zaio amari. Maialenek ez, Maialenek bere kasa egiten du lan. Marijoseren lagun batek ere bi seme ditu: Patxi (zaharrena) eta Gorka (gazteena). Hala, Marijosek hitzartua du bere alabetatik bat bere lagunaren semeetako batekin ezkotzeko. Ohiturari jarraiki, seme zaharrena besteak baino lehenago ezkondu behar da, 'premutza'-ren legeaz ezagutua dena. Jakinik ezkontzen den alaba urruti joan beharko dela bizitzera eta premutzaren legea ez bortxatzeko Marijosek Maialen Patxirekin ezkontzea erabakitzen du.

(16)-ko testuinguruan, (17)-ko perpausetako galdegaiek egibalio efektuak eragiten dituzte, apodosiaren interpretazioan eraginez:

(17a) Ez balu [Maialen $]_{F}$ ezkondu Patxirekin, Ainarak ezin izango zukeen amarekin lanean jarraitu.

(17b) Ez balu Maialen [Patxirekin $]_{\mathrm{F}}$ ezkondu, Ainarak ezin izango zukeen amarekin lanean jarraitu.

(17c) Ez balu [Maialen] $]_{\mathrm{F}}$ ezkondu Patxirekin, premutza bortxatu izango zukeen.

(17d) Ez balu Maialen [Patxirekin] $]_{\mathrm{F}}$ ezkondu, premutza bortxatu izango zukeen.

(17a) egiazkoa bada ere, (17b) gezurrezkoa da, berdin baitio Ainararen lan jardunerako Maialen norekin ezkontzen den. Horretarako garrantzitsua Ainara bera ez ezkontzea da. Halaber, (17c) gezurrezkoa da eta (17d) egiazkoa, premutzaren legeak seme zaharrena zain den begiratzen duelako, ez norekin ezkontzen den. Dretske (1972)$\mathrm{k}$ honelako egiturak arrazoimen-adierazpideekin lotzen ditu, efektu berdina agertzen baita. Honela (17)-ko baieztapenak (18)-n bezala arrazoi ditzakegu hurrenez hurren:

(18a) Patxirekin [Maialen $]_{\mathrm{F}}$ ezkontzeko arrazoia, Ainara bere lanerako beharrezkoa izatea da.

(18b) Maialen [Patxirekin $]_{F}$ ezkontzeko arrazoia, Ainara bere lanerako beharrezkoa izatea da. 
(18c) Patxirekin [Maialen $]_{\mathrm{F}}$ ezkontzeko arrazoia, premutza errespetatzea izan da.

(18d) Maialen [Patxirekin $]_{\mathrm{F}}$ ezkontzeko arrazoia, premutza errespetatzea izan da.

Aurrekoekin bezalatsu, (18a) egiazkoa da eta (18b) faltsua, eta (18c) faltsua eta (18d) egiazkoa. Areago, honelako egiturek oro har aurresuposizionalak diren perpaus alboratuak (cleft sentence) ere onartzen dituzte (19a) eta (19d) egiazkoak izanik, eta (19b) eta (19c) gezurrezkoak (ik. Rooth (1999)):

(19a) Ez balitz [Maialen] $]_{\mathrm{F}}$ izan Patxirekin ezkondu zena, Ainarak ezin izango zukeen amarekin lanean jarraitu.

(19b) Ez balitz [Patxi $]_{\mathrm{F}}$ izan Maialenekin ezkondu zena, Ainarak ezin izango zukeen amarekin lanean jarraitu.

(19c) Ez balitz [Maialen $]_{F}$ izan Patxirekin ezkondu zena, premutza bortxatu izango zukeen.

(19d) Ez balitz [Patxi $]_{\mathrm{F}}$ izan Maialenekin ezkondu zena, premutza bortxatu izango zukeen.

Ebidentzia honek irmoki pentsarazten du Geurts \& van der Sandt-ek proposatu bezala galdegaiak aurresuposizioak eragiten dituela, bestela hauen efektuak esplikaezinak genituzke-eta ${ }^{6}$.

\section{2: Galdegai Mota desberdinak ote?}

Galdegaiaren izaerarekin hertsiki loturik, beste arazo bat eztabaidatzen da literaturan: izan al daiteke hainbat motatako galdegaiak izatea, bakoitza interpretazio jakin batekin? Honek galdegaiaren aurresuposizioaren eztabaida semantikoari funtsa kenduko lioke, azken finean bi ikuspegiak liratekeelako zuzenak, bi fenomeno desberdinez ariko ginatekeelako. Jarraian (2.2.1-2.2.4 ataletan) literaturan aipatu diren galdegai 'mota' nagusiak aurkeztuko ditut horien izaera aldarrikatzeko erabili diren argudioekin batera. Argudio hauen kritikatik abiatuz, ondoren, galdegaiaren interpretazioaren azterketa bat egingo dut (2.2.5 atala). Honela, defendatuko dut galdegaiak dituen efektu kontrastiboak ez zaizkiela balizko alternatiba-multzo eta baieztapen-operatzaileei zor.

\subsection{1: Galdegai Informatiboa vs. Galdegai Identifikatiboa}

\footnotetext{
6 Badira, hala ere, beraien analisiarentzako arazoak. Geroago aztertuko dugun (6d)-ko esaldiaz gain, Rooth (1999)-ek ohartu bezala (ik. ere Jäger (2004) eta Geurts \& van der Sandt (2004b)), (i)-ko B-ren bigarren esaldiak ezin du aurresuposatu 'inork A-ren badminton erraketa hartu duenik’:

(i) A: Inork nire badminton erraketa hartu al du?

B: Ez dakit. [Jonek] $]_{\mathrm{F}}$ hartu badizu, ahaztu zaitez osorik bueltatzeaz.

Geurts \& van der Sandt-en analisiaren arabera, honelako kasu batean aurresuposizioak aurrekaririk ez duenez, lokalki egokitu beharra dago datuez kontu emateko. Hemen proposatuko dudan sistemak ere, printzipioz, ez luke arazorik A-k sartutako gertakariari erreferentzia anaforikoa egiteko (ik. 3. atala), baina nire iritziz, kasu honetan berbaldia ez da horren koherentea eta akaso, honelako egituretan 2.2.3-n ikusiko ditugun 'galdegai enfatikoa' dituzkegu. Etorkizunerako langai utziko dut afera.
} 
Szabolcsi (1981)-k hungarieraz gauzapen sintaktiko desberdinak dituzten bi galdegai-mota badirela defendatzen du: 'galdegai informatiboak' perpausaren ezkerreko periferian eta 'galdegai identifikatiboak' in situ (ik. ere Kiss (1998) horretarako). Galdegai informatiboak hondoan informazioa gehitu besterik ez du egiten, galdegai identifikatiboak, aldiz, galdegaiaren exhaustibitatea ere azpimarratzen du. Bi galdegai mota hauen arteko aldea, ikusgarriki, galdegai mota bakoitza ager daitekeen egitura sintaktikoetan exhaustibitate-testak aplikatuz agertzen da. Lehenengo testa, zuzenketazko esaldi-segida bat da, non bigarren esaldi batean lehenengoan galdegaia osatzen zuen Determinatzaile Sintagmari (DP) beste DP bat koordinatzen zaion galdegaiaren barruan:

(20a) Janos nem [Marit $]_{\mathrm{F}}$ hívta meg. [Marit és Évát $]_{\mathrm{F}}$ hívta meg. Janos ez Mari gonbidatu part. Mari eta Eva gonbidatu part. "Ez zen Mari izan Janosek gonbidatu zuena. Mari eta Eva izan ziren"

(20b) *Janos nem hívta meg [Marit $]_{\mathrm{F} .}$ Meghívta [Marit és Évát $]_{\mathrm{F}}$. Janos ez gonbidatu part. Mari. gonbidatu Mari eta Eva "Janosek ez zuen Mari gonbidatu. Mari eta Eva gonbidatu zituen"

Szabolcsi-ren arabera, (20a)-n bi esaldiak bata bestearen ondoan egiazkoak badira ere, (20b)-ko esaldi-segida gezurrezkoa gertatzen da, hain zuzen (20a)-ko galdegaiak exhaustiboak direlako eta (20b)-koak ez.

Elordieta (2001)-ek, hungarierazko exhaustibitate test hau euskarari aplikatzen dio, honako datuak emanez:

(21a) *Jonek [Miren $]_{\mathrm{F}}$ ez zuen gonbidatu. [Miren eta Amaia $]_{\mathrm{F}}$ gonbidatu zituen.

(21b) $*[\text { Miren }]_{\mathrm{F}}$ ez zuen gonbidatu Jonek. [Miren eta Amaia $]_{\mathrm{F}}$ gonbidatu zituen.

Elordietak argudiatzen duenez, bai (21a)-k eta bai (21b)-k, kontraesangarriak diren baieztapen-segidak dituzte, eta horregatik biak txarrak dira. Honela bada, autore honen arabera, euskaraz ezkerretan agertzen zaigun galdegaia, hungarierazkoa ez bezala, ez da identifikatiboa, eta informazio berria gehitzea besterik ez du egingo.

Szabolcsi-ren bigarren testa honakoa da: bi esaldi baditugu, non lehenengoak koordinatutako bi DP galdegaian dituen eta bigarrenak soilik bi DPetako bat, bigarren esaldia ez bada lehenengoaren ondorio logiko bezala interpretatzen, galdegaia exhaustiboa delako seinale, bestela, informatiboa litzateke:

(22a) Mari [egy kalapot és egy kabátot] nézett ki magának. Mari bat txapel eta bat beroki hartu part. berak "Txapel bat eta beroki bat hartu zituen beretzako Marik"

\#Mari [egy kalapot] $]_{\mathrm{F}}$ nézett ki magának. Mari bat txapel hartu part. berak “Txapel bat hartu zuen beretzako Marik”

(22b) Mari ki nézett magának [egy kalapot és egy kabátot] $]_{\mathrm{F}}$. Mari part. hartu berak bat txapel eta bat beroki "Marik beretzako txapel bat eta beroki bat hartu zituen" 
Mari ki nézett magának [egy kalapot] $]_{F}$.

Mari part. hartu berak bat txapel

"Marik beretzako txapel bat hartu zuen"

Szabolcsi-k dioenez, (22a)-ko bigarren esaldiak kontraesana eragiten du lehenengoarekin, hain zuzen ere hungarieraz ezkerretako galdegaia exhaustiboa delako. (22b)-n, aitzitik, ez dago kontraesanik, bigarren esaldia lehenengoaren ondorio logikoa izanik.

Elordieta (2001)-eko euskarazko datuak hauexek dira:

(23a) [Txapel bat eta soineko bat $]_{\mathrm{F}}$ erosi zituen Mirenek.

[Txapel bat $]_{\mathrm{F}}$ erosi zuen Mirenek.

(23b) Mirenek [txapel bat eta soineko bat $]_{\mathrm{F}}$ erosi zituen.

Mirenek [txapel bat $]_{\mathrm{F}}$ erosi zuen.

Lan horretako intuizioen arabera, (23a) eta (23b)-ko bigarren esaldiak lehenengoen jarraipen zuzenak dira, lehenengo esaldien ondorio logikoak izanik. Beraz, Elordietaren ondorioa galdegai hauek ez-exhaustiboak direla da, hots, informatiboak direla. Hori berrestuz, gurutzaketa ahulen datuak aztertzen ditu. Bere aburuz, (24)-ko esaldietan asimetria bat nabari da, (24a)-n gurutzaketa ahula dago (berak * bat ematen dio adibideari), baina (24b) eta (24c)-an aldiz, ez. Honela, gurutzaketa ahulik ez egoteak galdegaiaren operatzaile izaera zalantzan jarriko luke. Hau, Elordietarentzat galdegaia in situ dagoelako seinale da, eta hala izanik, egitura hauen forma logikoan Chomsky (1970)-k proposatutako <galdegai-aurresuposizio> egiturarik ez legokeela:

(24a) Nor ${ }_{\mathrm{i}}$ agurtu du bere aitak? $^{2}$

(24b) $\left[\mathrm{Jon}_{\mathrm{i}}\right]_{\mathrm{F}}$ agurtu du bere $\mathrm{aitak}$.

(24c) Bere aitak ${ }_{\mathrm{i}}\left[\mathrm{Jon}_{\mathrm{i}}\right]_{\mathrm{F}}$ agurtu du.

Nik ez dut uste halabeharrez horrela denik, berak ematen dituen datuekin ez bainator bat ${ }^{7}$. Nire intuizioen arabera, lehen irakurketa ez bada ere, indizekidetza (24)ko esaldi guztietan da posible. Eta posible baldin bada, gurutzaketa ahularen testak ez luke ezer erakutsiko. Hots, nire intuizioen arabera, gurutzaketa ahularen testak ez luke ez ukatuko ez eta baieztatuko galdegaia lekuz mugitu denik ${ }^{8}$. Areago, jarraian argudiatuko dudanez, galdegaiak oro har, interpretazio kontrastiboa izaten du.

\subsection{2: Galdegai kontrastiboa?}

Galdegai informatibo eta identifikatiboaren eztabaidan Elordieta (2001)-ek caveat bat sartzen du: ematen dituen datuen interpretazioa kontraste-testuingururik eta enfasirik gabe ahoskatuak direnean agertzen diratekeenak dirateke, posible baita esaldi hauen irakurketa kontrastiboa egitea 'testuinguruak kontraste multzo bat ematen duenean'. Kontua da berak ematen dituen exhaustibitate testuinguruetan beti dagoela

\footnotetext{
${ }^{7}$ Jakina, euskalki edo idiolekto arteko aldea izan daiteke hau eta ez dio Elordieta (2001)-eko analisiari ezer kentzen.

${ }^{8}$ Ik. beste alde batetik Kratzer (1991), non gurutzaketa ahularen efektuak galdegaiaren mugimendurik postulatu gabe azaltzen diren.
} 
kontraste testuinguru bat ((21)-n 'Miren' vs. 'Miren eta Amaia' eta (23)-n 'txapel bat' vs. 'txapel bat eta beroki bat'), eta nire intuizioen arabera, bada exhaustibitate efekturik. Honela, bere (23a) eta (23b)-ko datuen nire intuizioak (25a) eta (25b)-koak dira:

(25a) [Txapel bat eta soineko bat $]_{\mathrm{F}}$ erosi zituen Mirenek. \#[Txapel bat $]_{\mathrm{F}}$ erosi zuen Mirenek.

(25b) Mirenek [txapel bat eta soineko bat $]_{\mathrm{F}}$ erosi zituen. \#Mirenek [txapel bat $]_{\mathrm{F}}$ erosi zuen.

Besterik gabe, ez litzateke berbaldi egokirik (23a) edota (23b)-ko esaldi pareak elkarrekin kontraesanean izan gabe izan litzakeenik. Honela bada, aski naturalak egiten zaizkik bigarren esaldiak ekar dezakeen zuzenketa ikutua"

(26a) A: [Txapel bat eta soineko bat $]_{\mathrm{F}}$ erosi zituen Mirenek.

B: Ez, [txapel bat $]_{\mathrm{F}}$ erosi zuen Mirenek.

(26b) A: Mirenek [txapel bat eta soineko bat $]_{\mathrm{F}}$ erosi zituen.

B: Ez, Mirenek [txapel bat $]_{F}$ erosi zuen.

(21a) eta (21b)-ko adibideei dagokienez, ni ere bat nator Elordieta (2001)-en ematen diren intuizioekin, baina galdegaia eta ezeztapenaren arteko besarkadurari egotzi beharrekoak dirudite, izan ere (21a) eta (21b)-ko adibideetan Herburger (2000)-k galdegaiaren ezeztapenarekiko irakurketa askea deritzona baitugu, non ezeztapenaren besarkadurak aditza besterik ez duen hartzen. Honela, (21a) eta (21b)-ko adibideen lehenengo esaldiaren interpretazioa 'Jonek gonbidatu ez zuena Miren da'-ren parekoa litzateke. Eta hemendik, diskurtso-egiturak berak egiten ditu ezinezko (21)-ko perpaus segidak. Bestalde, galdegai eta ezeztapenaren besarkadura aproposak jarriz gero (non ezeztapenak ukagaiaren gaineko besarkadura hartzen duen (ik. de Rijk (1996), Ortiz de Urbina (2001)). Honela, esaldiak erabat naturalak egiten dira, eta galdegaiak interpretazio exhaustiboa du:

(27a) Jonek ez zuen [Miren $]_{F}$ gonbidatu. [Miren eta Amaia $]_{F}$ gonbidatu zituen.

(27b) Ez zuen [Miren $]_{F}$ gonbidatu Jonek. [Miren eta Amaia $]_{F}$ gonbidatu zituen.

Honenbestez, badirudi galdegaiak euskaraz beti interpretazio exhaustiboidentifikatibo-kontrastiboa duela.

Euskarari buruzko literaturan, beste bi galdegai-egitura mota aipatu izan dira galdegai mota desberdinen erakusgarri: galdegai enfatikoak eta eskuinaldeko galdegaiak.

\footnotetext{
luze batean sartuz gero:

(ii) A: [Txapel bat eta soineko bat $]_{\mathrm{F}}$ erosi zituen Mirenek.

B: Ez, [txapel bat $]_{\mathrm{F}}$ erosi zuen (Mirenek).

A: Ez, [txapel bat eta soineko bat $]_{\mathrm{F}}$

B: Ezetz, [txapel bat $]_{\mathrm{F}}$ erosi zuela...

A: Baita zera ere, [txapel bat eta soineko bat $]_{\mathrm{F}}$
}

${ }^{9}$ Exhaustibotasunik ez balego ulerkaitza litzateke (26)-ko B-ren esaldi hasierako ezeztapena, azken finean $\mathrm{B}-\mathrm{k} \neg(\mathrm{p} \wedge \mathrm{q})) \wedge \mathrm{p}$ motatako esaldi bat egiten du. Honela, aski arrunta gertatzen da egitura osoa eztabaida 


\subsubsection{Galdegai Enfatikoa:}

Etxepareren (1998)-ko lana aitzindaria da euskararen galdegaiaren interpretazio desberdinak eta hauekin doazen egitura sintaktiko zehatzak formulatzen. Bere analisiaren arabera, bi galdegai mota dituzkegu: galdegai enfatikoa eta galdegai kontrastiboa $^{10}$. E-galdegai enfatikoa konplementatzailearen espezifikatzailean A'-mugimendu bidez kokatua izango da eta perpausak adierazten duen gertakaria elkarrizketa-inplikatura baten bidez adieraziko du. Hau funtsean guk galdegai kontrastiboa deitu duguna da (irakurketa exhaustiboa darama eta galdegaiaurresuposizioa eragiten du):

(28) $[\text { Jonek }]_{\mathrm{F}}$ maite ditu patatak.

E-galdegai kontrastiboa, aldiz, inflexioaren proiekzioren batean A-mugimendu baten bidez kokatua izango da, eta perpausak adierazten duen gertakaria egiunezko inplikatura baten bidez adieraziko du. E-galdegai kontrastiboak harridura kutsu bat izango du, eta honenbestez, ez da exhaustiboa izango eta ez du galdegaiaurresuposiziorik eragingo. Areago, ez du halabeharrez, aditzarekin albokotasunik gorde beharko (ik. Etxepare (1998) xehetasunetarako):

(29) (Badakizu zer?), [Jonek $]_{\mathrm{F}}$ huts egin du!

(29) bezalako egoera batean harrigarria da Jonek gainditu ez izana eta hori da azpimarratzen dena. Honenbestez, E-galdegai kontrastiboak ez du aurresuposiziorik eragingo, ez eta exhaustibitaterik (kasu honetan, oso litekeena da beste norbaitek ere huts egin izana, bestela (29) tokiz kanpo legoke). Alta, badirudi E-galdegai kontrastiboetan perpaus osoa dela galdegai, (29)-ren kasuan enfasia edo harridura 'Jon'-engan jarriz. Egitura hauek, hortaz, antza handia dute ingelesezko 'Schmerling adibideekin' (ik. Schmerling (1976), Cinque (1993)): oro har, ingelesez, galdegaiazentua galdegaiaren sintagmarik menderatuenean egoten bada ere (30a), egitura hauetan ordea, galdegai-azentua aditz ezakusatibo bateko subjektuan egonagatik perpaus osoa izan daiteke galdegai (30b). Honela, azentua duen subjektua eta predikatuaren arteko loturaren harridura adierazten da (omen AEBko Truman presidentearen heriotza espero zen zerbait zen (30a) baina Johnsonena bat-bateko gertakaria izan zen (30b)) :

\section{(30a) [Truman DIED] $]_{F}$ \\ Truman hil \\ “Truman hil da”}

(30b) [JOHNSON died $]_{\mathrm{F}}$

Johnson hil

“Johnson hil da”

\footnotetext{
${ }^{10}$ Galdegaiei esleitzen zaizkien izenak gurutzatzen direnez eta nahasmenik ez sortzeko Etxepareren galdegaiei 'E-galdegai enfatikoa’ eta 'E-galdegai kontrastiboa' deituko diet aurrerantzean.
} 
Honela bada, nik E-galdegai kontrastiboetan, ingelesezko 'Schemrling adibideetan' bezalatsu, galdegaia perpaus osoa dela esango nuke (horregatik heien aurresuposiziorik eta exhaustibitaterik eza). Gainerakoa, baliteke harriduraren efektuak izatea $^{11}$.

\subsubsection{Zuzenketazko Eskuinaldeko Galdegaiak:}

Azkenik, euskaraz badira beste galdegai-egitura batzuk galdegai mota desberdinen erakusgarri erabili direnak: eskuinaldeko galdegaiak (ik. Osa (1990), Hualde, Elordieta \& Elordieta (1994), Elordieta (2001), Ortiz de Urbina (2003), Irurtzun (2005) datu eta analisi desberdinetarako). Egitura hauetan, oro har perpausaren ezkerraldean agertzen den galdegaia izan beharrean, galdegaia perpausaren eskuin mugan agertzen da:

(31) Jonek ekarri du [baloia $]_{\mathrm{F}}$.

Honelako egiturak, oso testuinguru kontrastibotan erabiltzen ohi dira, askotan aurreko esaldi baten zuzenketa egiteko. Bestalde, ezker periferiako galdegaiaren propietate bertsuak erakusten ditu besarkadurari dagokionez. Honela bada, Ortiz de Urbina (2003) eta honetan oinarrituz Irurtzun (2005)-k ezkerretaratutako galdegai mugimendu ezkutatu baten bidez azaltzen dute egitura, galdegai mugimenduaren osteko hondarraren topikalizazioz.

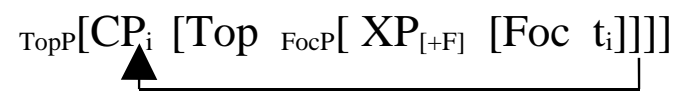

Beraz, ezkerretako galdegaia eta eskuinetakoa bera dira, aldatzen dena hondoaren kokapen sintaktikoa izanik (eta honekin batera, ezkerretaratutako hondoaren lotura irakurketa eta eskuinekoaren isats irakurketa (ik. Vallduví (1993)) ${ }^{12}$. Beti ere kontrastiboak dira.

Honenbestez, esaldiren bat ahoskatzen dugunean, galdegaia ezker muturrean ala eskuinean egon, hondoa galdegaiari eta galdegai horri bakarrik aplikatzen zaiola baieztatzen dugu. Hau da, galdegaiak irakurketa enfatiko-kontrastiboa du. Ikus, adibidez, (33)-ko solasaldia, non oraintxe aipatutako bigarren exhaustibitate-testa (ik. (22)) erabiltzen den lehen esaldian eskuinaldeko galdegaia erabiliz eta bigarrenean ezkerrekoa:

(33) A: Mahaia altxatu dute [Aitorrek eta Imanolek $]_{\mathrm{F}}$.

B: [Aitorrek $]_{\mathrm{F}}$ altxatu dute mahaia.

Halaber (34)-ko lehen exhaustibitate testarekin (ik. (20)), non A-ren esaldian ezkerretako galdegaia dugun eta B-renean eskuinetakoa:

(34) A: [Aitorrek $]_{\mathrm{F}}$ altxatu du mahaia.

B: Mahaia altxatu dute [Aitorrek eta Imanolek $]_{F}$.

\footnotetext{
${ }^{11}$ Mila esker Ricardo Etxepareri gai honen inguruko iruzkinengatik

${ }^{12}$ Vallduví (1993)-ren link eta tail-ez ari naiz, hurrenez hurren.
} 
Nire intuizioen arabera, B-k, bai (33)-n eta bai (34)-n A zuzentzen du, hots, A-k gezurra esaten duela dio $^{13}$. Demagun egoera bat non delako mahaia pisutsua eta handia den. Eta bi pertsonaren indarra behar izan den hura altxatzeko; Aitor eta Imanolena. Honelako egoera batean, aditzak lorpen bat adierazten duelarik, ezin esan 'Mahaia Aitorrek altxatu duenik', bien (Aitor eta Imanolen) indar kumulatiboak altxatu baitu (ez batak, eta ez besteak ${ }^{14}$ ). Horregatik B-ren zuzenketa bi kasuotan erabat naturala da. Areago, (35) eta (36)-ko segidak, non B-k A-ri arrazoia ematen dion, ez dira naturalak:

(35) A: Mahaia altxatu du [Aitorrek $]_{\mathrm{F}}$.

B: \#Bai, [Aitorrek eta Imanolek $]_{\mathrm{F}}$ altxatu dute mahaia.

(36) A: [Aitorrek $]_{\mathrm{F}}$ altxatu du mahaia.

B: \#Bai, mahaia altxatu dute [Aitorrek eta Imanolek $]_{\mathrm{F}}$.

Galdegai hauek, guztiek, interpretazio exhaustibo/kontrastibo/identifikatibo-rik ez balute, esaldiok ezingo genituzke esplikatu.

\subsection{5: Beraz? Kontrastea bai, baina Alternatibarik Ez}

Ikusi dugunez, euskarazko galdegaiak beti izango ditu interpretazio kontrastiboidentifikatibo exhaustiboak. Hauen kontu, printzipioz, alternatiben semantikak modu erraz batean eman diezaguke. Atal honetan ordea, alternatiben semantika zalantzan jartzeko argudioak emango ditut.

Hasteko, $[[\Phi]]^{\mathrm{F}}-\mathrm{n}$ alternatiben multzo bat izanik ez da aski kontraste interpretazioa lortzeko, zerbait gehiago behar da. Horretarako, adibidez, Krifka (1999)-k baieztapen operatzaile isil bat proposatzen du. Operatzaile honek, galdegaiak eragindako beste alternatibak ukatuko lituzke:

(37) BAIEZTATU(M, A, c) (M esanahia eta A alternatibak dituen perpaus bat $c$ testuinguruan baieztatzen da):

- hiztunak M (c-n) baieztatzen du.

- edozein $M^{\prime}$ alternatibarentzako, non $M^{\prime} \in A, M^{\prime} \neq M$, hiztunakm esplizituki ez du M’ (c-n) baieztatzen.

Operatzaile isil honek, oro har, galdegaiaren funtzio kontrastiboaz kontu emango liguke: alternatiba sorta bat dugunean, horietako bat hautatu eta besteak 'ukatzen' (hots, 'esplizituki ez baieztatzen') dira; hemendik kontrastea. Aitzitik, alternatiben semantikak baditu berekin arazo larriak, segidan ikusiko dugunez. Honela, azpiatal honetan alternatiben semantikaren aurkako argudioak emango ditut hurrengoan (2.3) galdegaiaren interpretazioaren orokorpenak emateko. Azkenik 3. atalean alternatiba multzoak eta (37)-ko operatzaile isila proposatu gabe, galdegaiaren interpretazioentzako

\footnotetext{
${ }^{13}$ Jakina, berriro ere, B-ren erantzuna naturalagoa zatekeen hasieran A-renaren ukazio esplizitu batekin: “Ez! ...”. Hau ere, B-ko galdegaien kontrastibitatearen erakusgarri.

${ }^{14}$ Honelako gertakariak gutxienez bi modutara azal daitezke: gertakariaren subjektua pluralitate bat bezala aztertuz (ik. Link (1983)), ala bi azpigertakari ditugula esanez (bakoitza bere subjektu singularrarekin), bien batura mereologikoaren ondorioz mahaiaren altxamendua gertatuz (ik. Schein (1993)).
} 
analisi semantiko-pragmatiko bat proposatuko dut gertakarien semantikan oinarrituz. Baina aurretik, esan bezala, alternatiben semantikaren arazo batzuk aipatuko ditut.

Hasteko, alternatiben semantikaren funtsean bada oinarrizko ahultasun bat: galdegai-aurresuposizioak ukatzea, eta honekin hiztunaren aurreikuspenak erabat zapuztea, testuinguru gehienetan galdegai-aurresuposizioa badelako intuizioa zuzena baita. Hots, Herburger (2000)-k argudiatu bezala, teoria hau kasurik txarrenaren gainean eraikitako orokorpen batean oinarritzen da. Aurresuposiziorik ez dagoela esateak, hiztuna gertakariaren egitatearekiko erabat ezjakina dela baieztatzea dakar, eta kasurik gehienetan ez dirudi hala denik. Adibidez, (38)-ko galderan badirudi A hiztunak norbait etorri dela aintzat hartzen duela eta, hala, B-ren erantzunak A-ren aurresuposizioak zapuzten ditu ${ }^{15}$ :

(38) A: Nor etorri da?

B: $[\text { Inor }]_{F}$ ez da etorri.

Geurts eta van der Sandt-ek, honelako datuek sortuko luketen arazoa saihesteko polaritate edo verum galdegai bezala aztertzen dituzte, non galdegaia ez litzatekeen perpauseko osagai soil bat baizik eta perpausaren polaritatea. Honek, jakina, aski ad hoc dirudi, hasteko, ezezko polaritate elementua edozein (subjektu, osagarri...) izan daitekeelako. 3. atalean datuoi analisi alternatibo bat eskainiko diet Herburger (2000)ren ildotik.

Beste alde batetik ere, alternatiba multzotan eraikitako teoria batek ez dirudi hiztunaren I-hizkuntzaren ezagutza semantikoaz kontu emateko aproposena, izan ere, gaitasun konputazional izugarriak egozten dizkio hiztunari. Alternatiben semantika ereduen semantikan oinarritzen da, non giza hizkuntzaren baten semantika irudikatzeko, hizkuntza artifizial baten bidez eredu bat osatzen den bertan banakoak eta erlazioak (multzoak) definituz (ik. Montague (1973)). Funtsean, honelako semantika baten ikuspegitik, hizkuntza bateko adierazpen baten estentsioa adierazpen horrek denbora eta mundu jakin batean denotatzen duen objektua da. Hala, eredu txiki eta itxi batean, aski erraza da alternatibak modelatzea: 5 banako besterik ez baditugu, demagun \{Jon, Miren, Aitor, Mikel, Leire\} eta propietateren bat, demagun, \{galiziarra izatea\} banako bakar bati badagokio, (39)-n erantzunak ondoko esanahia luke, non alternatiba multzotik bakar bat hautatzen den besteak 'esplizituki ez baieztatuz':

(39) A: Nor da galiziarra?

B: $\left[\left[[\text { Aitor }]_{\mathrm{F}}\right.\right.$ da galiziarra $\left.]\right]=$

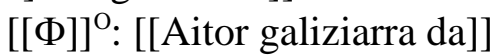

$[[\Phi]]^{\mathrm{F}}:\{[[$ Jon galiziarra da $]]$, [[Miren galiziarra da]], [[Aitor galiziarra da]], [[Mikel galiziarra da]], [[Leire galiziarra da]]\}

Honelako errepresentazio semantiko bat izanik, modu natural batean jaso dezakegu galdegaiaren kontraste izaera, baina, errealista al da? Nik uste ezetz, postulatzen diren alternatiben multzoek mugagabeak izan behar dutelako. Adibidez:

(40) A: Zein da zure zenbaki faboritoa?

B: [Zortzia $]_{\mathrm{F}}$ da.

\footnotetext{
${ }^{15}$ Ik. Hintikka (1976), Belnap \& Steel (1976).
} 
Argiki, galde-erantzun honen errepresentazio semantikoak ez luke mugarik. Informalki aurkeztuta:

(41) A: Zein da zure zenbaki faboritoa?

B: $\left[\left[[\text { Zortzia }]_{\mathrm{F}} \mathrm{da}\right]\right]=$

$[[\Phi]]^{\mathrm{O}}$ : [[B-ren zenbaki faboritoa $\left.\left.8 \mathrm{da}\right]\right]$

$[[\Phi]]^{\mathrm{F}}: \quad\{[[$ B-ren zenbaki faboritoa 0 da]], [[B-ren zenbaki faboritoa 1 da]], [[B-ren zenbaki faboritoa 2 da]], [[Bren zenbaki faboritoa 3 da]], [[B-ren zenbaki faboritoa 4 da]]...\}

Jakina, kontestualismoaren ikuspegitik, argudia liteke alternatiba multzoa testuinguruaren arabera eskuragarri dauden zenbaki faborito 'ohikoenetara' murrizten dela (ik. Rooth (1992), von Fintel (1994)). Honela, konputazio infinitua saihestuko litzateke $^{16}$. Baina, jarraian ikusiko denez, testuinguruko murriztapenek ez dute askorik lagunduko. Eman dezagun eguneroko egoera bat:

(42) A: Zein da loterian saritutako zenbakia?

B: 67.568a.

Loterian zenbaki oro da kontestualki garrantzitsua, eta estatistikoki aukera berdinak ditu saridun izateko, beraz, forma logikozko errepresentazioan banako positibo guztiak egon beharko lirateke (Espainiako loteriaren kasuan 100.000 artekoak gutxienez, hor baitago espainiar loteriaren txartelen muga). Berriro ere, argudia liteke hala ere alternatiben multzoa nolabait txikia eta mugatua dela. Halakoetan egonez gero, egin froga honekin:

(43) A: Zenbat supernova daude unibertsoan?

B: 367.

Demagun galdera egiten duenak 'supernova' hitza entzuna duela, badakiela argizagiren bat denotatzen duela, baina, ideiarik ez astronomiaz, eta ez dakiela honelakoak unibertsoan banaka batzuk edo bilioiak diren (nire kasua adibidez). Horregatik, eta bere ezjakintasunarekin bukatzeko astronomo bati A-ko galdera egiten dio. Kasu honetan, alternatiben multzoa, kontestualismoaren murriztapen epistemikoak gehituta ere ez dirudi mugatzen erraza, galdegile ezjakinaren buruan bilioika alternatiba daudekeelako; funtsean batere mugarik gabe.

Arazoa, jakina, ez da zenbakietara mugatzen (bestela arazoak irtenbide intentsionalen bat izan lezake-eta). Ikus (44)-ko adibidea.

(44) A: Zein da zure izena?

B: [Oswaldo $]_{\mathrm{F}}$.

Galde-erantzuna argi dago, A-k B-ri izenaz galdetzen dio eta B-k izen batekin erantzuten. Baina, hemen ez dago multzo finkorik; hots, zein da izen nagusien multzoa? Jakina, testuinguruak kasu batzuetan lagun lezake balizko izenen multzoa mugatzen

\footnotetext{
${ }^{16}$ Alta, ez horren erraz, azken finean testuinguru-aldagaiak, domeinuaren gainean eraikitako [[Ф]] ${ }^{\mathrm{F}}$ balio semantikoa murriztu beharko baitu (ik. Rooth (1985) eta Martí (2004) eztabaidarako).
} 
(aurrean duzun pertsonaren sexua, jatorria eta abar iragarrita), baina ez da laguntza handikoa izango testuinguru urriko egoeretan, demagun interneteko chat batean. Hala ere galde-erantzunak erabat naturalak dira. Gainera, kasu honetan B-k soilik izenarekin erantzun du, baina, Espainiako ohiturari jarraiki izen eta bi abizen eman izan balitu (demagun 'Oswaldo Basanoaga Heredia' dela), zein da konbinaketatik ateratzen zaigun alternatiba-multzoa? Potentzialki mugagabea, ez baitago daitezkeen izenekiko mugarik.

Berdintsu gertatzen da diskurtsoan batere lotu gabeko galderen erantzunekin. Honelako galderetan NZ-hitzak ordezkatuko lukeen multzorik agerian ez dagoenez, erantzunean ere ez dirudi beharrezkoa denik ${ }^{17}$ :

(45) A: Nor arraio ibili da nire gauzetan?

$\mathrm{B}:[\mathrm{Ni}]_{\mathrm{F}}$ ibili naiz.

Intuitiboki, kontrastea bada; hau da, badago 'ni eta beste inor ez' irakurketa, baina ez dago alternatiba-multzorik.

Halaber, Chosmky-ren lehen lanetatik ezaguna da hizkuntza baten perpaus multzoa mugagabea dela (giza-hizkuntzen alderdi sortzailearen propietate behinenetarikoa mugagabetasun diskretua izaki ${ }^{18}$ ). Honela bada, ikus (46) eta (47)-ko elkarrizketak:

(46) Buff.. [Athletic salbatuko dela espero dut, bestela, edozein astakeria egiteko gai naiz $]_{\mathrm{F}}$.

(47) A: Zer egingo zenuke miss hautatua izanez gero?

B: [Munduan bakea zabaltzen saiatu $]_{\mathrm{F}}$.

Argi eta garbi, eta testuinguruari nahi diogun funtzio murriztailea emanik ere, (46) eta (47)-ren altenatiba-multzoak mugagabeak dira. Ez dira asko, mugagabeak baizik. Eta honek esaldiok interpretaezinak egin beharko lituzke esanahia mundu eta denbora batean edukietatik objektuetarako funtzio batek erabakitzen badu. Gainera, Lepore (1983)-k argudiatu bezala, espresio baten esanahia jakiteko delako espresioak benetako munduan hautatzen dituen objektuak (eta espresioa galdegaia bada, bere alternatibak ere) zein diren ezagutu behar badugu arazo gaitza dugu, 'benetako' mundua zein den jakin beharko genukeelako aldez aurretik.

\section{3: Ondorioak: Galdegaia, aurresuposizioa eta kontrastea}

Atal honetan ikusitako datuen arabera, galdegai-egituretan, oro har, exhaustibitate eta kontrastibitate efekturik badela ondorioztatu beharko dugu. Aitzitik, efektu hauek zeri egotzi ez dago argi, hasteko, beti hartu behar dugulako aintzat berbaldiaren natura informatiboa. Adibidez, Grice (1975)-en lehenengo kantitate maximak derrigorrez erantzun batean galdetzen zaigun informazio guztia ematera behartzen gaitu. Honela bada, kontraste efektua nolazpait pragmatikoa izan liteke. Bestalde, ikusi ditugun testuinguru handirik gabeko esaldietan ez dirudi batere

\footnotetext{
${ }^{17}$ Ingelesez, agressively non D-linked deritzonez ari naiz (ik. Pesetsky (1987) besteren artean). Mila esker Maia Duguineri argudioaren iradokizunagatik.

${ }^{18}$ Ik. besteren artean Hauser, Chomsky \& Ficht (2002).
} 
kontrasterik dagoenik. Benetako adibide bakarrak egiazki out-of-the-blue diren esaldiak iruditzen zaizkit, propotipikoki, egunkarietako titulu ereduak: honelako titulu eredu batean ez dagoke ezer aurresuposatuta, ez ezer kontrastean, eta kasurik gehienetan ez dute 'zer gertatu da?' galderarik; honek jada 'zerbait gertatu delako' aurresuposizioa eragiten baitu. Jakina, baliteke ere perpaus osoko galdegai batek irakurketa kontrastiboa izatea, baina kasu hauetan mendeko perpaus baten galdegaia genuke, ez perpaus nagusiarena ('gertatu dena da [Aitor etorri dela $]_{\mathrm{F}}$ '). Honenbestez, jarraian, arestian aipatutako esaldiak izango ditut gogoan out-of-the-blue edo proposizio-galdegaiak aipatzean: egiazki osoki informazio berria direnak, egunkari bateko titulu prototipikoak $^{19}$.

Badirudi, beraz, galdegaia perpauseko partehartzaile bat denean badirela halako kontraste efektuak, baina galdegaia proposizio oso bat denean ez dela halako efekturik. Beraz, galdegaiak interpretazio kontrastibo eta ez kontrastiboak izan ditzakeela ondorioztatuko dut.

Laburbilduz, eztabaida honetatik hiru ondorio nagusi atera daitezke:

(i) Osagai-galdegaiak funtzio exhaustiboa badu.

(ii) Funtzio exhaustiboa ez da alternatiba multzoen bidez lortzen, ez baitago alternatiba multzorik.

(iii) Proposizio-galdegaiak ez du funtzio kontrastatzailerik.

Orain, erantzun beharreko galdera honakoa da: zerk eragiten ditu interpretazio alde hauek? Ikusi bezala, korrelazio argi bat dagoela dirudi: osagai-galdegaia, ezkerretakoa, kontrastibo bezala interpretatzen da, eta perpaus-galdegaia, non ez dirudien ezer mugitzen denik, soilik informatibo bezala.

Honela bada, interpretazio-alde hau galderaren denotazio semantiko eta berbaldiaren antolaketa pragmatikotik deribatzen dela proposatu nahi nuke; hitz gutxitan: out-of-the-blue galdera baten erantzuna den proposizio batek ezingo du eman Groenendijk \& Stokhof (1982)-k galderaren erantzun exhaustibo gogorra deritzotena, hots, galderak eskatzen duen egiazko informazio guztia eta egiazko informazio guztia hori delako informazioa. Hau da, out-of-the-blue galdera baten erantzunak beti izango direla erantzun partzialak. Osagai-galdegaia duen erantzun batek, ordea, testuinguruak lagunduta adieraziko du erantzun exhaustibo bat (ik. ere Higginbotham \& May (1981)). Adibidez, (48)-ko kasuetan, (48a)-ko osagai-galderaren erantzuna entzunda, entzuleak 'beste inor etorri ez dela' inferitu dezake galderari erantzun exhaustibo bat bilatzeko (hainbat faktore pragmatiko tarteko ${ }^{20}$ ). Aldiz, (48b)-ko out-of-the-blue galderaren erantzuna entzunda, entzuleak ezin du inferitu 'beste ezer gertatu ez denik':

(48a) A: Nor etorri da?

B: $[\text { Mikel }]_{\mathrm{F}}$ etorri da.

(48b) A: (Zer gertatu da?)

B: [Mikel etorri da $]_{\mathrm{F}}$

\footnotetext{
${ }^{19}$ Eta esan bezala, galdegai hauek batere testuingururik gabe sartuak badira ere, nik argitasunerako 'zer gertatu da?’ galdera parentesi artean erabiltzen jarraituko dut galdegai informatiboari sarrera emateko.

${ }^{20}$ Hauek, Grice (1975)-n lehenengo kantitate maximaren bidez azal litezke.
} 
Argudiatuko dudanez, galdegaiaren exhaustibitatearen afera honek ez ditu egingo galdegai 'mota' desberdinak, interpretazio desberdintasunak beste nonbaitetik ondorioztatuko direlako (ik. 3. atala). Ohar, bestela ere, hainbat galdegai 'mota' badirela defendatzeak galdera teoriko garrantzitsuak berekin lituzkeela, oraingoz literaturan erantzuteke dauden galderak: hasteko, ez dago argi zer ezkutatzen den 'mota' hitzaren atzean, hau da, ez dago argi zein diren halako teoria baten primitibo teorikoak: funtsean; zeintzuk dira tipoak eta zeintzuk adibideak ${ }^{21}$ ? Galdegai informatiboa eta identifikatiboaz gain badirateke-eta beste 'mota' batzuk: enfatikoak (hainbat enfasi gradurekin), baldintzazkoak, galderazkoak, verum galdegaiak, ukagaiak eta beste hainbat. Argudiatu dudanez, interpretazio desberdinak badirela argi da, baina zerk egiten ditu galdegai desberdin? Galdegai informatiboa eta galdegai kontrastiboa informazio-egituraren bi primitibo al dira? Hala bada, biak perpaus berean ager daitezke? Sintagma bat izan al daiteke ald berean galdegai informatibo eta galdegai kontrastibo? Ez badira bi primitibo desberdin, zein da biak batzen dituen primitiboa? Tasun kontu bat da? Konfigurazio kontu bat? Hala bada, nola lortzen ditugu deribazionalki? Ikusten denez, kontua da zertan oinarri gaitezkeen galdegaiaren bi erabileren arteko alde kategorial bat markatzeko.

Lan honetan, esan bezala, ikuspegi murriztaile bat burutzen saiatuko naiz, galdegaia bat eta bakarra dela defendatuz. Gainerako xehetasunak, konplementatzailearenetik ondorioztatzen direla argudiatuko dut.

Jarraian, propietate hauetaz kontu emateko nire semantikaren proposamena egingo dut.

\section{§3-Proposamena: Galdegaia Gertakari Gaineko Kuantifikazioen Besarkaduran}

Atal honetan, lan honetako ekarpen nagusia emango dut, galdegai-moten efektuak hautapen lexikotik ondorioztatzen direlako ideia: forma logikoetan gertakarien gaineko kuantifikazioak baditugu, kuantifikazio mota desberdinek irakurketa mota desberdinak eragingo dituzte. Horretarako, 3.1 atalean nire lana oinarrituko dudan Herburger (2000)-ko proposamena laburbilduko dut eta 3.2-an Herburgerrenaren nire moldapena.

\section{1: Eredu Semantikoa: Gertakari Gaineko Kuantifikazioa}

Galdegaidun espresioen forma logikoa emateko Herburger (2000)-ren proposamena moldatuko dut. Herburgerrek Davidson (1967a)-rekin hasi eta bestek moldatutako gertakaritan oinarritutako semantikaren ildoko proposamen bat egiten du. Ikuspegi neo-Davidsondar honen arabera, perpaus bat funtsean gertakari baten deskripzioa da, non predikatuak gertakariaren edukia zehazten duen. Honela, partehartzaileak (atributuak) gertakariarekin $\theta$-rolen bidez lotutako predikatuak dira, eta elkarren artean konjuntzio bidez koordinatuak dira (ik. Parsons (1991), Schein (1993) eta Pietroski (2005), besteak beste). Honela bada, (49a)-ko perpausari (49b)-ko forma logikoa legokioke ${ }^{22}$ :

\footnotetext{
${ }^{21}$ Hemen, ingelesez type-token banaketa deitzen denaz ari naiz.

${ }^{22}$ Ikuspegi honetan oinarrizko ideia bat $\theta$-rolen uniformetasuna izango da (ik. Larson \& Segal (1995)), zeinak $\theta$-rol bakoitza behin esleitua dela segurtatuko digun. Formalki: $\theta$-rol guztientzat, $\forall \mathrm{e} \forall \mathrm{x}[\theta(\mathrm{x}, \mathrm{e}) \rightarrow$ $\forall y[\theta(y, e) \rightarrow x=y]]$
} 
(49a) Jonek pilota eraman du.

(49b) Эe [eraman(e) \& Egile(e, Jon) \& Gai(e, pilota) \& Orain(e)]

Galdegai efektuei dagokienez, Herburgerrek gertakarien gaineko kuantifikatzaile existentziala bitarra dela proposatzen du. Kuantifikatzaileak bere murriztapenean esaldiaren 'eztabaidagaia' hartuko du (hots, galdegai ez den guztia, hondoa) eta besarkaduran esaldi osoa, galdegaia barne ${ }^{23}$ :

(50a) [Jonek $]_{\mathrm{F}}$ eraman du pilota.

(50b) $\exists$ e [eraman(e) \& Gai(e, pilota) \& Orain(e)] Egile(e, Jon) \& eraman(e) \& Gai(e, pilota) \& Orain(e)

Honelako forma logiko batek, galdegaiaren ohiko kasuez kontu emateaz gain Jackendoff-en beheranzko kuantifikatzailearen arazoa ere saihestuko du, arazoa kuantifikatzaile-besarkadurara murriztuz. Hasierako (6d)-ko esaldiak (hemen (50a) bezala errepikatuta) (50b)-ko forma logikoa luke:

(50a) $[\text { Nobody }]_{\mathrm{F}}$ likes Bill.

(50b) [INOR x] [ $\exists$ e [maite(e) \& Gai(e, Peru) \& Orain(e)] Esperimentatzailea(x) \& maite(e) \& Gai(e, Peru) \& Orain(e)

Gainera, Herburgerrek aipatzen ez badu ere, sistema hau aintzat hartzeak gainerako abantaila garrantzitsuak ere baditu, hots, esaldi guztietan galdegai bat izateko beharra forma logikoaren errepresentaziotik ondorioztatzea. Izan ere, funtzionalki, hau da, informazio-egituraren arabera begiratzen badugu, beti bada ongi eratutako eta aproposa den esaldi batean galdegaitzat jo dezakegun zerbait, dela esaldiaren zati bat (predikatuaren argumentuetariko bat, adibidez (51)) (dela esaldi osoa (delako esaldia out-of-the-blue edo testuinguru murriztailerik gabe ahoskatua denean, (52)-n bezala)):

(51a) Nork ebatsi du liburua?

(51b) [Aitorrek] $]_{\mathrm{F}}$ ebatsi du liburua.

(52a) (Zer gertatu da?)

(52b) [Aitorrek liburua ebatsi du $]_{\mathrm{F}}$.

Hau funtzionalki egitate bat da; esaldiek beti informazioren bat gehitzen dute ${ }^{24}$. Kontua da lehen aipatutako Rooth-en sistemari jarraiki, galdegaiaren beharra axiomatizatu egin beharko litzatekeela forma logikoan, hau da, printzipioz, ez dirudi ezertaz ondorioztatzen denik esaldi orok hainbat esanahi-dimentsio izan behar dituenik. Aitzitik, lan honetan garatuko dugun ereduak indukzioz ondorioztatzen du propietate hau: gertakarien gaineko kuantifikatzaileak besarkadurarik hartzen ez badu, kuantifikazio hutsala gertatzen baita:

\footnotetext{
23 Arrazoi enpirikoak ematen ditu Herburgerrek honetarako, beude, baina kuantifikatzaileen kontserbakortasunak eragiten duen murriztapen bat da besarkaduran murriztapena ere errepikatzea.

${ }^{24}$ Grice (1975)-en “Kooperazio Printzipioa”- ren bidez azal genezake hau.
} 
(53) Kuantifikazio Hutsalaren Aurkako Debekua (Kratzer (1995)): Q kuantifikatzaile ororentzako, $\mathrm{x}$ aldagai bat izan behar da non eta Q-k x-ren agerpen bat uztartzen duen, bai murriztapenean eta baita besarkadura nuklearrean ere.

Honela, besarkadurarik hartzen ez badu, gertakarien gaineko kuantifikatzaileak murriztapen hori bortxatuko du eta deribazioa irakurgaitz edo gaizki osatutakoa gertatuko da forma logikoan (ik. Potts (2002) eztabaidarako). Puntu garrantzitsua, proposatzen dudan ereduak galdegaiaren beharra indukzioz ondorioztatzen duela da: forma logiko irakurgarriek berez duten murriztapen bat dela medio, esaldi orok izango du galdegai bat.

\section{2: Bi Kuantifikazio Mota}

Herburgerren proposamenak modu elegante batean ematen digu galdegaiaren propietateen kontu, baina badira azaldu beharreko arazoak: alde batetik, kuantifikatzaile existentziala bitartzat jotzen du. Honek berez ez du inongo arazorik sortzen, baina indefinituen semantikan oro har aintzat hartzen denarena aurka doa. Beraz, Herburgerren proposamena bere horretan mantendu nahi badugu, bi alorretan (banako mailan eta gertakari mailan) kuantifikatzaile existentzialak dituen propietateak desberdinak direla postulatu behar dugu. Beste alde batetik, kuantifikazioaren murriztapenari ematen zaion balio diskurtsiboaren zehazgabetasuna dago. Herburgerren proposamenean, galdegaiak ez ditu aurresuposizioak eragiten, eta honek, (50a)-ko datuen berri emateko balio badio ere, 2. atalean aipatutako datuek ez lukete azalpen errazik. Gainera, bestela ere, Herburgerrek kuantifikazioaren murriztapenari esleitzen dion funtzioa esaldiaren 'eztabaidagaia' zehaztea dela dio, 'eztabaidagai' hori zer den zehaztu gabe. Azkenik, proposamen honek alternatiba-semantikak kontraste intuizioa esplikatzeko zuen gaitasuna galtzen du, intuizio horren azalpena erabat pragmatikaren eskutan utziz. Hala bada, azaldu gabe gelditzen zaigu zergatik kasu batzuetan baden halako kontrasterik eta besteetan ez. Hots, pisu handiegia egozten zaio zehaztu gabeko prgamatika bati.

Honela bada, atal honetan Herburgerren proposamenari egingo dizkiodan moldapen batzuk eta horien zergatiak azalduko ditut, horien bidez, datu gatazkatsuak azaltzeko.

Berriro ere gogora ekarriz 2. atalean esandakoa, badirudi esaldi osoa galdegai denean honek ez duela inongo kontrasterik sortzen:

(54a) (Zer gertatu da?)

(54b) [Aitorrek telebista puskatu du $]_{\mathrm{F}}$

Bestalde, galdegaia perpauseko osagaietako bat denean, esaldiak interpretazio kontrastiboa hartzen du:

(55a) Nork puskatu du telebista?

(55b) [Aitorrek $]_{\mathrm{F}}$ puskatu du telebista. 
Iragar daitekeen bezala, kontraste ezaren propietatea aurresuposiziorik ezarenarekin fermuki loturik ageri da. Honela bada bi propietateok txanponaren bi alde direla iradoki nahi dut (1)-eko bi eztabaida ardatzak batera ekarriz.

Hau argitzeko, egin nahi dudan proposamena honakoa da: galdegai zabala, esaldi osokoa, murriztu gabeko kuantifikazio existentzial baten bidez emana da. Hots, (56a)-ko galdera erantzungo lukeen (56b)-ko esaldiari dagokion forma logikoa (56c)koa dela:

(56a) (Zer gertatu da?)

(56b) [Jonek patatak erosi zituen $]_{\mathrm{F}}$

(56c) $\exists$ e [Erosi(e) \& Lehen(e) \& Egile(e, Jon) \& Gai(e, patatak)]

Forma logiko honek berekin ditu galdegai hauei dagozkien propietateak: murriztapenaren hutsetik aurresuposizio-eza ondorioztatzen da, eta gertakarien gaineko kuantifikatzaile existentzialetik, galdegai informatiboa izatea, azken batean, gertakarien deskripzio indefinituak banakoen deskripzio indefinituak bezalaxe, berbaldian lehen aldiz berbaldi edota banako bat sartzeko erabiliko dira.

Osagai-galdegaietan, berriz, egitura konplexuagoak dituzkegu, Hegarty (1992)-k proposatutako $\delta$-kuantifikatzaileen ildotik eraikiak. Autore honek, aditz faktiboen aurresuposizionaltasunaz kontu emateko $\delta$ kuantifikatzailea proposatzen du, zeinak gertakarien deskripzio definituak egingo dituen ( $\mathrm{l}$ kuantifikatzaileak banakoekin egiten duen bezalaxe). Nik, Hegarty-ren proposamena Herburgerrenarekin uztartuko dut galdegai estudun esaldi bat gertakari baten deskripzio definitua dela proposatuz, non gertakariaren dependentzia anaforikoa kuantifikatzailearen murriztapenean izango den ${ }^{25}$. Honela bada, (57a)-ko galdera erantzuten duen (57b)-ko perpausak (57c)-ko forma logikoa duela proposatzen dut:

(57a) Zer erosi zuen Jonek?

(57b) $[\text { Patatak }]_{\mathrm{F}}$ erosi zituen Jonek.

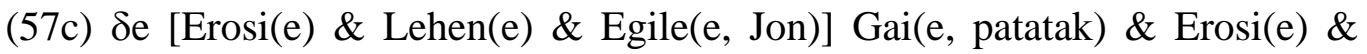
Lehen(e) \& Egile(e, Jon $)^{26}$

Forma logiko honek baditu iragarpen onak berekin: hasteko, $\delta$ kuantifikatzailearen bitartasuna espero izatekoa da, azken batean hau bai baita

\footnotetext{
${ }^{25}$ Hegarty-k, bere proposamenaren inplementazioa Heim (1982)-ren File Change Semantics ildoan egitea proposatzen du, non gertakari-deskripzioak ere txartel bat sartuko duen berbaldiaren markoan (ik. Heim (1982) eta Hegarty (1992)). Ni, ordea, eredu dinamiko honen hautaketatik aldenduko naiz, eta besterik gabe $\delta$ kuantifikatzailearen anaforikotasuna hartuko dut aintzat. Hau da, gertakari hauek aitzindari bat eskatuko dute.

${ }^{26}$ Forma logiko honek ((56c)-koak bezalatsu, berez ez dizkigu perpausaren egibalioak emango, egitura kuantifikazional bat besterik ez baita. Horretarako, egibalioen ikuspegi Fregearrari jarraiki, egia eta gezurra esaldiek balio bezala hartzen dituzten objektuak direla aintzat hartuko dut eta, Tarski-ren "Tkonbentzioaren" moldapen Davidsondarrari jarraiki (ik. Davidson (1967b) "P egiazkoa da baldin P" formula 'desaipatzailea' erabiliko dut, non perpausek (p) $<$ t, $\mathrm{p}>$ edo $<\mathrm{f}, \mathrm{p}>$ baliotze bat izango duten (eta ' $\mathrm{t}$ '= egiazkoa eta ' $\mathrm{f}$ '= gezurrezkoa). Hau da, (57a) adibidearentzako:

(iii) Balio(t, 'Jonek erosi ditu patatak') bsb $\delta \mathrm{e}[\operatorname{Erosi}(\mathrm{e}) \&$ Orain(e) \& Egile(e, Jon)] Gai(e, patatak) \& Erosi(e) \& Lehen(e) \& Egile(e, Jon)

Hots, 'Jonek erosi ditu patatak' perpausak t balioa hartzen duela baldin eta soilik baldin patatak erosi dituena Jon bada (ik. Higginbotham (1985), Larson \& Segal (1995), Pietroski (2005)). Dena dela, eta azalpenaren argitasunaren mesedetan (57c) bezalako forma logikoak besterik ez ditut irudikatuko.
} 
kuantifikatzaile sendo bona fide bat. Bestalde, deskripzio definituaren bakartasunaren murriztapenetik kontraste efektuak naturalki eta alternatibarik postulatu gabe ondorioztatuko dira, izan ere, deskripzio definituak, propietate hori betetzen duen gertakaria bakarra izatea eskatzen baitu (ik. Kadmon (2001) besteak beste) ${ }^{27}$. Azkenik, bere murriztapenaren balio anaforikotik aurresuposizio efektuak naturalki ondorioztatzen dira, diskurtsoan aipatutako gertakariez ari behar garelako. Ohar, bidenabar, honelako proposamen batekin galdegaiak ez duela aurresuposizio existentziala eragin beharko, eta hau ona da, bigarren atalean argudiatu bezala, konpromiso existentziala gogorregia baita. Gertakarien deskripzio definituen proposamenarekin, soilik izaera anaforiko bat izan beharko du. Eta jakina, anaforaren bidez adierazten den gertakariak ez du zertan 'benetako' existentziarik izan behar. Honekin zera esan nahi dut: galdegaiak eragindako aurresuposizioa ez da existentziala izan behar, anaforikoa baizik. Hots, Stalnaker (1974) eta Karttunen (1974)-ri jarraiki, aurresuposizioa testuinguruan inposatutako murriztapen bat bada, galdegai aurresuposizioa, gertakariaren anaforikoatsunetik ondorioztatuko da; existentziakonpromisorik gabe. Hala, hitz egin dezakegu (6d) eta (50a)-n aipatu eta gertatu ez den gertakari horretaz (hemen (58a) bezala errepikatua):

(58a) $[\text { Nobody }]_{\mathrm{F}}$ likes Bill.

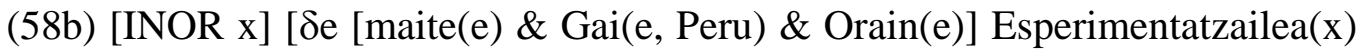
\& maite(e) \& Gai(e, Peru) \& Orain(e)

Modu berean ere, ez diren gertakariei erreferentzia egin diezaiekegu, ikus, adibidez (59):

(59) Ez dezazula amets egin zu eta nire artean gertatuko ez denarekin.

(59)-ko 'zu eta nire artean gertatuko ez dena'-k gertakari bat adierazten badu ere (zu eta nire artean gertatuko ez dena hain zuzen ere), gertakari hau ez da gertatu, gertakizun baita ${ }^{28}$. Honela bada, funtsean, osagai-galdegaien anaforikotasunarekin, diskurtso-antolakuntzako galdegaiaren egokitasun-printzipioak ondoriozta ditzakegu, eta Jacobs (2004)-k, Geurts eta van der Sandt (2004a)-ri eginiko iruzkinean asmatzen duen (60)-ko Hondo-Berbaldi Araua-ren efektuak, independenteki behar ditugun lanabesek emango dizkigute (deskripzio definitu eta erlazio anaforikoek):

(60) Hondo-Berbaldi Araua: S perpaus baten $\mathrm{u}^{\mathrm{s}}$ esaldi batek $\lambda x . \varphi(\mathrm{x})$ hondoa eragiten duen Galdegai-Hondo egitura aske bat baldin badu (non eta galdegaia ez doan operatzaile batekin), orduan $\mathrm{u}^{\mathrm{s}}$ egokia da soilik $\lambda x . \varphi(\mathrm{x}) \mathrm{u}^{\mathrm{s}}$ aurreko berbaldi zatian eztabaidapean izan bada.

Ikusten denez, ez dugu honelako arau berezirik espresuki postulatu behar izango, gertakarien deskripzio definituen anaforikotasunak jada $\lambda x . \varphi(\mathrm{x})$ hondoaren eztabaidapekotasuna segurtatzen baitu.

\footnotetext{
${ }^{27}$ Lan honetan, ez naiz sartuko gertakari pluralen arazoan, arazo aski korapilatsua baita; ik. Schein (1993) horretarako.

${ }^{28}$ Halaber gertatzen da ez dauden objektuekin: 'zirkulu karratua', 'kolorerik gabeko ideia berdeak'... Ezin esan 'existitzen’ direnik, ez badira diskurtsoan existitzen.
} 
Beste alde batetik, arestian aipatutako birkuantifikazioaren arazoari modu natural batean emango zaio konponbidea arazoaren agerrera bera ukatuz. Lehen aipatutako (11) eta (13) adibideak hemen (61a) eta (62a) bezala errepikatuz, hauen forma logikoak (61b) eta (62b)-koak izango dira hurrenez hurren ${ }^{29}$ :

(61a) Zakur bat normalean [adimentsua $]_{\mathrm{F}}$ da.

(61b) Gehien(s) [izan(s) \& [ $\exists$ x: zakur(x)]] izan(s) \& [ $\exists$ x: zakur(x)] adimentsu(x)

(62a) Beso bat normalean [ezkerreko $]_{F}$ sorbaldari atxikia dago.

(62b) Gehien(s) [atxiki(s) \& [ $\exists x$ : beso(x)] \& Gai(s, x) \& [ $\exists y$ : sorbalda(y)] Leku(s, y)] atxiki(s) \& [ $\exists$ x: beso(x)] \& Gai(s, x) \& [ $\exists$ y: sorbalda(y)] Leku(s, y) \& ezker(y)

Iragar daitekeenez, honelako forma logikoekin arazoa bera ez da agertuko. Azken finean, aldagaiei edozein balio esleituta ere, murriztapenaren balioak eta besarkadurarena berdinak izan behar dute, izan ere $[x=x]$ eta $[y=y]$.

Laburbilduz, osagai-galdegaiak aurresuposizionalitate efektuak sortzen ditu; eta aurresuposizio hauen agerrera espero izatekoa da osagai-galdegai bat dugunean gertakari baten deskripzio definitua badugu. Deskripzio definituei dagozkien bakartasun murriztapenek ere galdegai hauei dagozkien exhaustibitate efektuak modu naturalean iragarriko dituzte. Bestalde, diratekeen out-of-the-blue galdegaiak gertakarien gaineko kuantifikatzaile existentzial batek sortuko ditu, honenbestez, ez dute aurresuposiziorik ez eta exhaustibitaterik izango.

Bukatzeko, osagai-galdegai eta out-of-the-blue galdegaiaren artean dagoen beste alde nabarmen bat: osagai-galdegaia perpausaren ezker-periferian agertzen da eta outof-the-blue galdegaian ez dirudi ezer mugitu denik. Hau azaltzeko, gertakari gaineko kuantifikatzailea konplementatzaile sisteman kodetuta dagoela iradoki nahi nuke; hain zuzen ere Finiteness buruan (ik. Rizzi (1997), Irurtzun (2006)). Honela, konplementatzaile sistema desberdinak izango ditugu esaldiaren testuinguru eta aurresuposizionaltasunaren arabera: Konplementatzaile Sintagma (CP) zatitu aberats bat osagai-galdegaia duten esaldietan (63a), eta CP soil bat testuingururik gabeko out-ofthe-blue esaldietan (63b). Hauen zehaztapena konplementatzaile buruak $\left(\mathrm{C}^{\circ}\right)$ dituzkeen selekzio murriztapenen araberakoa izango da:

(63a)

$\begin{array}{rrrr}\text { CP } & & \\ 2 & & \\ \text { Espez. } & \text { C' } & \\ 2 & & \\ \text { C }^{\circ} & \text { TopP } & \\ & 2 & & \\ & \text { Espez } & \text { Top' } \\ & 2 & \\ & & \text { Top }^{\circ} \quad \text { FocP } \\ & & \end{array}$

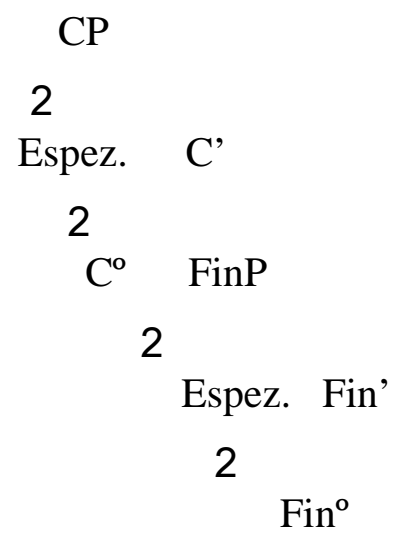

$[\ldots]$

\footnotetext{
${ }^{29}$ Parsons (1991)-i jarraiki, egoerentzat 's' aldagaia erabiliko dut, baina ez da ezer sakonik ondorioztatu behar tipografia-hautu honetaz.
} 
Espez. FocP

2
Foc $^{\circ}$ FinP
2
Fin $^{\circ} \quad[\ldots]$
$(=\delta)$

Osagai-galdegaietan galdegai-burua dugunez $\left(\mathrm{Foc}^{\circ}\right)$, honek galdegaiaren mugimendua eragingo du bere espezifikatzailera sintaxi irekian. Forma Logikoan Irurtzun (2006)-en proposatutako 'erreproiekzioaren' bidez, behar dugun egitura kuantifikazionala lortuz (ik. lan hori xehetasunetarako). (63b)-n aldiz, egitura soilagoa izango dugu, sintaktikoki sinpleagoa (ez baitago mugimendurik eragingo duen Foc $^{\circ}$ galdegai bururik) eta semantikoki ere sinpleagoa Fin $^{\circ}$ predikatu monadikoa izango baita. Hau da, testuingurudun esaldi bat dugunean eta testuingururik gabekoa dugunean konplementatzaile egitura desberdina izango dugu, hizketa-ekintza desberdinak kodetzen.

\section{§4-Ondorioak}

Lan honetan argudiatu denez, galdegai mota desberdinak proposatzeko ez dago arrazoirik, testuingururik duen galdegaiak beti efektu berdinak dituelako: galdegaiaurresuposizioak eragin eta exhaustibitatea baieztatu. Testuingururik gabeko galdegaietan (out-of-the-blue deritzanetan) ordea, bestelakoak dira interpretazioak: ez dago aurresuposiziorik eta ez dago exhaustibitaterik. Aldea, aitzitik, ez dagoke galdegaian berean, egitura bakoitzaren konplementatzaile-sisteman baizik: testuingururik gabeko esaldiek informazio berria besterik ez dute emango, hala gertakarien gaineko kuantifikatzaile existentzial batez definituak izango dira. Testuingurudun galdegaietan ordea, galdegai aurresuposizioa eta exhaustibitatea izango ditugu, testuinguruan aipatuak diren gertakarien deskripzio definituak direlako.

\section{Erreferentziak:}

Belnap, N. D. \& T. B. Steel, 1976, The Logic of Questions and Answers, New Haven (CT): Yale University Press.

Cappelen, H. \& E. Lepore, 2005, Insensitive Semantics: A Defense of Semantic Minimalism and Speech Act Pluralism, Malden (MA) \& Oxford: Blackwell.

Chomsky, N., 2005, “On Phases”, eskuizkribua: MIT.

Chomsky, N., 2004, "Beyond Explanatory Adequacy”, in A. Belletti (arg.), Structures and Beyond: The Cartography of Syntactic Structures vol. 3, Oxford: Oxford University Press, 104-131.

Chomsky, N., 1977, “On Wh Movement”, in P. Culicover, T. Wasow \& A. Akmajian (arg.), Formal Syntax, New York (NY): Academic Press, 71-132r.

Chomsky, N., 1976, "Conditions on Rules of Grammar", in Linguistic Analysis 2-4: 303-51.

Chomsky, N., 1970, "Deep Structure, Surface Structure and Semantic Interpretation." in R. Jakobson \& S. Kawamoto (arg.), Studies in General and Oriental Linguistics, 
Tokyo: TEC Corporation for Language Research, 183-216. [Berrarg. in D. Steinberg \& L. Jakobovits (arg.), Semantics in Generative Grammar, New York: Cambridge University Press, 183-216. ]

Cinque, G., 1993, “A Null Theory of Phrase and Compound Stress”, in Linguistic Inquiry 24-2, 239-297.

Davidson, D. 1967a, “The Logical Form of Action Sentences”, in N. Rescher (arg.), The Logic of Decision and Action, Pittsburgh: University of Pittsburgh Press. [Berrarg. in D. Davidson, 2001, Essays on Actions and Events, New York (NY): Oxford University Press, 105-122].

Davidson, D., 1967b, “Truth and Meaning”, in Synthese 17, 304-323.

Dretske, F. I., 1972, “Contrastive Statements”, in The Philosophical Review 81-4, 411437.

Elordieta, A., 2001, Verb Movement \& Constituent Permutation in Basque, Doktorego tesia: Universiteit Leiden.

Etxepare, R., 1998, “A Case for Two Types of Focus in Basque”, in E. Benedicto, M. Romero \& Tomioka (arg.), UMOP 21: Proceedings of Workshop on Focus, Amherst (MA): GLSA, 65-81.

von Fintel, K., 1994, Restrictions on Quantifier Domains, Doktorego tesia: UMass.

García Murga, F., 1998, Las Presuposiciones Lingüísticas, Bilbo: EHU.

Geurts, B. \& R. van der Sandt, 2004a, "Interpreting Focus”, in Theoretical Linguistics 30, $1-44$.

Geurts, B. \& R. van der Sandt, 2004b, “Interpreting Focus Again”, in Theoretical Linguistics 30, 149-161.

Gómez, I., 2002, Foco y Tema: Una Aproximación Discursiva, Bilbo: EHU.

Grice, H. P., 1975, "Logic and Conversation”, in Cole, P., \& J. L. Morgan, (arg.), Speech Acts, New York: Academic Press, 41-58.

Groenendijk, J. eta M. Stokhof, 1982, "Semantic analysis of wh-complements”, in Linguistics and Philosophy, 5(2), 175-233.

Hamblin, C. L., 1973, “Questions in Montague English”, in Foundations of Language 10, 41-53.

Hauser, M. D., N. Chomsky \& W. T. Fitch, 2002, “The Faculty of Language: What Is It, Who Has It, and How Did It Evolve?”, in Science 298, 1569-1579.

Hegarty, M., 1992, Adjunct Extraction and Chain Configurations, Doktorego tesia: MIT.

Heim, I., 1982, The Semantics of Definite \& Indefinite Noun Phrases, Doktorego tesia: UMass.

Herburger, E., 2000, What Counts: Focus \& Quantification, Cambridge (MA): MIT Press.

von Heusinger, K., 1999, Intonation \& Information Structure, Habilitationsschrift: U. Konstanz.

Higginbotham, J., 1985, “On Semantics”, in Linguistic Inquiry 16-547-593.

Higginbotham, J. \& R. May, 1981, "Questions, Quantifiers and Crossing”, in The Linguistic Review 1, $41-80$.

Hintikka, K. J. J., 1976, “The Semantics of Questions and the Questions of Semantics”, in Acta Philosophica Fennica 28-4.

Hornstein, N., 1995, Logical Form: From GB to Minimalism, Oxford: Blackwell. 
Hornstein, N., 2002, “A Grammatical Argument for a Neo-Davidsonian Semantics”, in G. Preyer \& G. Peters (arg.), Logical Form and Language, Oxford: Oxford University Press, 345-364.

Hualde, J. I. \& J. Ortiz de Urbina, 2003, A Grammar of Basque, Berlin: Mouton de Gruyter.

Hualde, J. I., G. Elordieta \& A. Elordieta, 1994, The Basque Dialect of Lekeitio, EHU \& Gipuzkoako Foru Aldundia: Bilbo \& Donostia.

Irurtzun, A., 2005, "Reprojection \& Spell Out (or Vice-versa)”, XV. Colloquium on Generative Grammar-en, U.de Barcelona, Bartzelonan emandako hitzaldia.

Irurtzun, A., 2006, "Focus \& Clause Structuration in the Minimalist Program”. In C. Boeckx (arg.), Minimalist Essays, Amsterdam: John Benjamins, 68-96.

Jackendoff, R., 1972, Semantic Interpretation in Generative Grammar, Cambridge (MA): MIT Press.

Jacobs, J., 2004, “Focus, Presuppositions, and Discourse Restrictions”, in Theoretical Linguistics 30, 99-110.

Jäger, G., 2004, “Alternatives or Presuppositions? A Comparison of the BackgroundPresupposition Rule with Alternative Semantics”, in Theoretical Linguistics 30, 11-122.

Kadmon, N., 2001, Formal Pragmatics, Malden (MA) \& Oxford (UK): Blackwell.

Karttunen, L., 1973, "Presuppositions of Compound Sentences” in Linguistic Inquiry 42, 169-193.

Karttunen, L., 1974, "Presuppositions and Linguistic Context", in Theoretical Linguistics 1, 181-194.

Kiss, K. É., 1998, “Identificational Focus versus Information Focus”, in Language 74-2, 245-273.

Kratzer, A., 1991, “The Representation of Focus”, in A. Von Stechow \& D. Wunderlich (arg.), Semantik. Ein internationales Handbuch zeitgenössischer Forschung. Berlin, New York: Walter de Gruyter.

Kratzer, A., 1995, “Stage-Level and Individual-Level Predicates as Inherent Generics”, in G. N. Carlson \& F. J. Pelletier (arg.), The Generic Book, Chicago (IL): University of Chicago Press, 125-75.

Krifka, M. (arg.), 2004, Theoretical Linguistics 30.

Krifka, M., 2001, "For a Structured Meaning Account of Questions \& Answers", in C. Féry \& W. Sternefeld (arg.), Audiatur Vox Sapientiae, Berlin: Akademie Verlag.

Krifka, M., 1999, “At least some determiners aren’t determiners”, in K. Turner (ed.), The Semantics/Pragmatics Interface from Different Points of View, Oxford: Elsevier, 257-291.

Larson, R. \& G. Segal, 1995, Knowledge of Meaning: An Introduction to Semantic Theory, Cambdrigde (MA) \& Londres: MIT Press.

Lepore, E., 1983, “What Model Theoretic Semantics Cannot Do?”, in Synthese 54, 167187.

Link, G., 1983, “The Logical Analysis of Plurals and Mass Terms: A Lattice-theoretical Approach” in R. Bäuerle-eta (arg.), Meaning, Use and the Interpretation of Language, Berlin: Walter De Gruyter [Berrarg. in P. Portner \& B. Partee (arg.), Formal Semantics: The Essential Readings, Oxford: Blackwell, 127-146.]

Martí, L., 2004, Contextual Variables, Doktorego tesia: UConn.

Montague, R., 1973, “The Proper treatment of Quantification in Ordinary English”, in K. J. J. Hintikka-eta (arg.), Approaches to Natural Language, Amsterdam: 
Kluwer, 221-242. [Berrarg, in P. Portner \& B. Partee (arg.), Formal Semantics: The Essential Readings, Oxford: Blackwell, 17-34.]

Ortiz de Urbina, J., 1989, Some Parameters in the Grammar of Basque, Dordrecht: Foris.

Ortiz de Urbina, J., 1999, "Focus in Basque", in Rebuschi \& Tuller (arg.), The Grammar of Focus, Amsterdam: John Benjamins.

Ortiz de Urbina, J., 2001, “Ezezko Perpausetako Fokoak (Galdegaiak eta Ukagaiak)”, in IKER 14, Bilbo: Euskaltzaindia, 343-356.

Ortiz de Urbina, J. 2003. Focus of Correction and Remnant Movement in Basque. In Erramu Boneta: A Festschrift for Rudolph P.G. De Rijk, J. Lakarra and X. Artiagoitia (eds.), Donostia: ASJU.

Osa, E, 1990, Euskararen Hitzordena Komunikazio Zereginaren Arauera, Leioa: EHUren Argitalpen Zerbitzua.

Parsons, T. 1991, Events in the Semantics of English, Cambridge (MA): MIT Press.

Pesetsky, D. 1987. "Wh-in situ: Movement an unselective binding”. in E. J. Reuland eta A. G. B. ter Meulen (arg.), The Representation of (In)definitiness, Cambridge, Mass.: MIT Press, 98-129.

Pietroski, M., 2005, Events and Semantic Architecture, Oxford: Oxford University Press.

Potts, C., 2002, "No vacuous quantification constraints in syntax", in M. Hirotani (arg.), Proceedings of the North East Linguistic Society 32. University of Massachusetts, Amherst: GLSA, 451-470.

de Rijk, R. P. G., 1969, “Is Basque an SOV Language?”, in Fontes Linguae Vasconum, 1, 319-351 or. [Berrarg. in de Rijk (1998), De Lingua Vasconum: Selected Writings, EHU \& Gipuzkoako Foru Aldundia: Bilbo \& Donostia, 13-38].

de Rijk, R. P. G., 1996, "Focus and Quasifocus in Basque Negative Statements", in Revista Internacional de Estudios Vascos 41-1, 63-76. [Berrarg. in de Rijk (1998), De Lingua Vasconum: Selected Writings, EHU \& Gipuzkoako Foru Aldundia: Bilbo \& Donostia, 421-433].

Rizzi, L., 1997, “The fine structure of the left periphery”, in L. Haegeman (arg.), Elements of Grammar, Dordrecht: Kluwer, 281-337.

Rooth, M., 1985, Association with Focus, Doktorego tesia: UMass.

Rooth, M., 1992, “A Theory of Focus Interpretation”, in Natural Language Semantics $1,75-116$.

Rooth., M., 1995, "Indefinites, Adverbs of Quantification and Focus Semantics”, in G. Carlson \& F. J. Pelletier (arg.), The Generic Book, Chicago: The University of Chicago Press, 265-299.

Rooth, M., 1999, “Association with Focus or Association with Presupposition?”, in P. Bosch \& R. Van der Sandt (arg.), Focus: Linguistic,Cognitive and Computational Perspectives, Cambridge: Cambridge University Press, 232-244.

Schein, B., 1993, Plurals and Events, Cambridge (MA): MIT Press.

Schmerling, S., 1976, Aspects of English Sentence Stress, Autstin (TX): Austin University Press.

Stalnaker, R., 1974, "Pragmatic presuppositions", in M. K. Munitz \& D. K. Unger (arg.), Semantics and Philosophy, New York (NY): NYU Press, 197-213.

Szabolcsi, A., 1981, “The Semantics of Focus-Topic Articulation”, in J. Groenendijketa (arg.), Formal Methods in the Study of Language 2, Amsterdam: Matematisch Centrum, 503-540. 
Vallduví, E., 1993, The Informational Component, Doktorego tesia: UPenn. 